\title{
Planning and Developing Outcome Based Engineering Curricula to Meet the Needs of Fast Growing Indian Industries
}

\author{
Dr.V.Thanikachalam \\ Executive Consultant in Engineering Education and HRD,Chennai-600041 \\ vthani2025@gmail.com
}

\begin{abstract}
Most of the engineering institutes are finding difficulties in developing outcome based engineering curricula to meet the needs of fast growing Indian industries and MNCs. The process of developing outcome based curricula is as follows:Preparation of matrix, analyzing the types of industries which would employ them, analysis of desired performances of graduates at entry, synthesis of abilities, and preparation of course outcomes, preparing curriculum framework, strategies to acquire professional abilities expressed as program outcomes as in EC2000, curriculum development approach, required key skills of the fresh graduates, tracer study, forming consortium of institutes, establishing satellite centers in the industrial hubs/ corridors for assessing the needs, accreditation criteria and the process for accreditation of outcome based curricula. If the institutes systematically plan the outcome based curricula and implement them through trained and qualified faculty and with cooperation with the companies, then the institutes can largely achieve success.
\end{abstract}

Keywords: Outcome based curricula, accreditation process, steps in implementing

\section{Dr.V.Thanikachalam}

Executive Consultant in Engineering Education and HRD,Chennai-600041

vthani2025@gmail.com

\section{Introduction}

There is a great need for outcome based engineering curricula and faithful implementation with adequate number of qualified and trained faculty. Many rural and semi urban institutes are facing many problems in establishing close relationships with the industries in the region. Shortage of the motivated students and trained technical support staff, not able to get the cooperation with the industries in the state, and limited resources at the disposal of the institutes are some of the problems. Some of the program educational objects seem to be very difficult for realization by the fresh graduates. Also the human resource requirements are changing due to the impact of IT enabled tools for analysis. This paper makes an attempt to provide possible solutions for these problems. It is learnt that improperly designed curricula which are implemented without ensuring the abilities in the graduates make them unemployable. It is a great loss to the society.

\section{Objectives}

口 Analyze the curriculumrequirements in various branches of engineering and technology in the fast developing industries.

$\square$ Suggest the process of acquiring professional abilities identified as program outcomes in EC2000.

( Suggest appropriate curriculum development process to prepare outcome based curricula in engineering and technology 
Q Identify the key result areas to implement the outcome based curricula.

\section{Literature Review}

Duyen Nguyen (1998) stated that industries should participate actively in the establishment of engineering workshops and laboratories for undergraduate programs to enhance the quality training and research. Industries/ academia cooperation in the areas of research and development with a view of establishing pilot projects and plants would enhance industrial experience of both teachers and students. Afonja, SrakuLartey and Oni based on their research work report that there is little or no faculty-employer interaction in the areas of curriculum development, research and consultancy in Ghana, Nigeria and Zimbabwe. Industry is generally unwilling to provide the support needed for gainful experience. In these countries academic staffhave very little engineering practice. Rajee et al have stated that in outcome based education, students are responsible for their own learning and the assessment of learning are based on the outcomes instead of the contents being taught. Many of the research workers even question the process of outcome based curricula. In the absence of active Industry-InstituteGovernment Partnership, the OBE is not going to produce effective engineers. High end learning outcomes need a lot of resources, guidance of senior engineers in the field. These high end professional abilities could be acquired over a period of extensive training in the real life. However, the graduates are expected show their willingness through their education and exposure to the cases.

\section{Majors Research Questions to be answered}

( Whether the most significant Educational Program Objectives (PEOs) have been identified for the fresh engineering graduates for the industry to which students are developed?

口 Whether the industry representatives / employers have accepted the PEOs?

口 Whether the learning outcomes planned for various courses are relevant?

口 Whether the sums of all learning outcomes contribute to the achievement of PEOs?

u Whether the learners possess adequate abilities to solve the professional challenges in real life situation?

૫ Do they have right attitude to professional ethics?

口 Will they engage in independent and life-long learning in the broadest context of technological change?

u Will he/she function as a member or leader in diverse teams and in multidisciplinary settings?

u Will he/she ensure public safety in their work?

․ Will they protect environment?

Every outcome based engineering curriculum should ensure positive answers to the above questions.

The following are some of the case studies which demonstrate the need for congruencies.

Table- 1.Course Outcomes and Program Educational Objectives.

\begin{tabular}{|l|l|l|l|l|}
\hline $\begin{array}{l}\text { Case } \\
\text { No. }\end{array}$ & Program & $\begin{array}{l}\text { Missing } \\
\text { Course }\end{array}$ & PEO & Impact \\
\hline 1. & $\begin{array}{l}\text { B.E(Civil } \\
\text { Engg) }\end{array}$ & $\begin{array}{l}\text { Town } \\
\text { Planning }\end{array}$ & $\begin{array}{l}\text { Ability to apply } \\
\text { knowledge of } \\
\text { mathematics, science, } \\
\text { engineering fundamentals } \\
\text { and engineering } \\
\text { specialization to solution } \\
\text { of complex engineering } \\
\text { problems. }\end{array}$ & $\begin{array}{l}\text { A civil engineer improperly } \\
\text { planned a residential layout in 5 } \\
\text { hectares site. Later court cases } \\
\text { have made him to prepare layout } \\
\text { asper the rules. In this process a } \\
\text { sum of five million was lost in } \\
\text { revising the layout and } \\
\text { reregistration. }\end{array}$ \\
\hline 2. & $\begin{array}{l}\text { B.E(Civil } \\
\text { Engg.) }\end{array}$ & $\begin{array}{l}\text { Soil } \\
\text { Mechanics- } \\
\text { Weak } \\
\text { regional } \\
\text { soil } \\
\text { deposits }\end{array}$ & $\begin{array}{l}\text { The design engineer of PWD } \\
\text { designed the buildings for an } \\
\text { education institute but the } \\
\text { buildings started settling to a depth } \\
\text { of 90 cm in 10 years. They } \\
\text { demolished the building and new } \\
\text { buildings were constructed. The } \\
\text { loss is INR 10 million. }\end{array}$ \\
\hline
\end{tabular}


There are many incongruences in many branches. They should be eliminated in the outcome based engineering curriculum planning. Hence, there is a need for the analyses of field failures which are available and an in-depth forensic analysis has to be done. Examples are software failures, energy consuming automobiles, improperly designed building, improper water management, and improper industrial design for forging machines.

More care has to be taken in planning outcome based interdisciplinary programs in engineering. Tracer studies would provide the difficulties faced by the alumni. 360 degree evaluation of formative evaluation of the draft curriculum and summative evaluation are very much required.

A Matrix for Planning Outcome Based Curriculum in Engineering

A matrix could be prepared for planning and developing the curricula:

Branch of Specialization; Current Industrial Practices and Human Resources required; Intellectual skills and competencies needed; Entry level Jobs available for the engineering graduates; Key performance areas for the new entrants; In-house training and development of the new employees. This would provide skills and competencies needed by the prospective employers.

Analysis of Performance, Synthesis of Abilities and Preparation of Course Outcomes

The data collected from the industries, the faculty could prepare the needed intellectual skills, competencies, list of major areas of performances that are expected from the fresh graduates, the needed abilities and synthesized course outcomes, (Table-2). The same could be edited by an expert from a company. A study of failures could provide in depth information on the effectiveness of the prepared curricula. The institutes could consider the program evaluation by considering the context with respect to economy (C), input from stakeholders (I), relevant educational change process $(\mathrm{P})$ and the most suitable graduates (products) (P).The suitable model is CIPP.

Table-2

\begin{tabular}{|l|l|l|l|l|}
\hline $\begin{array}{l}\text { Job Analysis } \\
\text { with respect to } \\
\text { intellectual } \\
\text { needs } \\
\text { (Professional } \\
\text { skills and } \\
\text { competencies) }\end{array}$ & $\begin{array}{l}\text { For a given job, } \\
\text { Task Analysis } \\
\text { and listing the } \\
\text { major } \\
\text { performance }\end{array}$ & $\begin{array}{l}\text { Desired } \\
\text { Performance of } \\
\text { the new } \\
\text { engineering } \\
\text { graduates }\end{array}$ & $\begin{array}{l}\text { Abilities Needed } \\
\text { from the fresh } \\
\text { graduates }\end{array}$ & $\begin{array}{l}\text { Planned Course } \\
\text { Outcomes to } \\
\text { inculcate the } \\
\text { abilities through } \\
\text { curriculum and } \\
\text { instruction }\end{array}$ \\
\hline & & & & \\
\hline
\end{tabular}

Curriculum Framework

The senior faculty members in cooperation with a company representative, the curriculum developer could prepare a list of course objectives and design appropriate courses (Table-3). These courses could be new or modified from the existing list. The outcomes of these courses have to be evaluated through alumni and employers. The sum of all these outcomes would provide the data on the success of the Program Educational Objectives.

Table-3

\begin{tabular}{|l|l|l|l|l|}
\hline Broad & Courses & Desired Course \\
Performance & $\begin{array}{l}\text { Type of } \\
\text { course } \\
\text { Areas }\end{array}$ & $\begin{array}{l}\text { Course } \\
\text { Planned }\end{array}$ & $\begin{array}{l}\text { Course } \\
\text { Objectives }\end{array}$ \\
& $\begin{array}{l}\text { Applied, } \\
\text { Core, } \\
\text { Advanced/ } \\
\text { Elective }\end{array}$ & & & \\
& & & & \\
\hline
\end{tabular}


Strategies to AcquireProfessional Abilities expressed as Program Outcomes in EC 2000

\section{Abilities}

The following abilities are indicated in EC 2000 of ABET. They are classified as core, advanced, human relations, professional and professional leadership. The brought titles of the courses are suggested. An effort has been made to suggest the process of inculcating the abilities. There may be many difficulties to achieve the advanced abilities and professional abilities by the fresh graduates. However, the institutes have to implement the suggestions through trained faculty and creating needed programs.

Table-4

\begin{tabular}{|l|l|l|l|}
\hline $\begin{array}{l}\text { Classific- } \\
\text { ation }\end{array}$ & Abilities & Courses & $\begin{array}{l}\text { Instruction, } \\
\text { Assignment, } \\
\text { Research, Capstone } \\
\text { Project, Dissertation }\end{array}$ \\
\hline Core & $\begin{array}{l}\text { To apply knowledge of } \\
\text { mathematics, science, engineering } \\
\text { fundamentals and an engineering } \\
\text { specialization to the solution of } \\
\text { complex engineering problems }\end{array}$ & $\begin{array}{l}\text { Mathematics, Applied } \\
\text { Physics, Applied } \\
\text { Chemistry, Material } \\
\text { Science, Basic } \\
\text { Engineering, Core } \\
\text { Engineering }\end{array}$ & $\begin{array}{l}\text { Instructional design } \\
\text { could provide field } \\
\text { orientation, } \\
\text { assignments to solve } \\
\text { the engineering } \\
\text { design, } \\
\text { manufacturing, } \\
\text { testing }\end{array}$ \\
\hline Core & $\begin{array}{l}\text { To identify, formulate, research } \\
\text { literature and analyze complex } \\
\text { engineering problems reaching } \\
\text { substantial conclusions using first } \\
\text { principles of mathematics, natural } \\
\text { sciences and engineering sciences }\end{array}$ & $\begin{array}{l}\text { Advanced courses, } \\
\text { Research, Mini- } \\
\text { projects, Critical } \\
\text { appraisal of the } \\
\text { existing solutions }\end{array}$ & $\begin{array}{l}\text { Group discussions, } \\
\text { Team based projects, } \\
\text { Capstone } \\
\text { projects,Industrial } \\
\text { visits, }\end{array}$ \\
\hline Core & $\begin{array}{l}\text { To design solutions for complex } \\
\text { engineering and design systems, } \\
\text { components or processes that meet } \\
\text { specified needs with appropriate } \\
\text { consideration for public health and } \\
\text { safety, cultural, societal and } \\
\text { environmental considerations }\end{array}$ & $\begin{array}{l}\text { Case studies in } \\
\text { excellence, Case } \\
\text { studies in failures, } \\
\text { Problems faced in } \\
\text { industrial disasters, } \\
\text { Impact of climate } \\
\text { change, International } \\
\text { human resource } \\
\text { management. }\end{array}$ & $\begin{array}{l}\text { Arojects based on the } \\
\text { industrial needs, } \\
\text { Visits to Regional } \\
\text { Labor Institutes } \\
\text { devices, Visits to } \\
\text { Industrial } \\
\text { Exhibitions, } \\
\text { Industrial Museums, } \\
\text { Participation in the } \\
\text { programs of the State } \\
\text { Science Societies }\end{array}$ \\
\hline
\end{tabular}




\begin{tabular}{|c|c|c|c|}
\hline Core & $\begin{array}{l}\text { To conduct investigation into } \\
\text { complex problems using research } \\
\text { based knowledge and research } \\
\text { methods including design of } \\
\text { experiments, analysis and } \\
\text { interpretation of data, and synthesis } \\
\text { of information to provide valid } \\
\text { conclusions }\end{array}$ & $\begin{array}{l}\text { Advanced } \\
\text { interdisciplinary/ } \\
\text { multidisciplinary } \\
\text { courses, } \\
\text { Projects through } \\
\text { interdisciplinary } \\
\text { teams, } \\
\text { experimentation } \\
\text { Participation in the } \\
\text { Quality Circles }\end{array}$ & $\begin{array}{l}\text { Industry specific } \\
\text { project development, } \\
\text { Advanced projects in } \\
\text { emerging technology, } \\
\text { Projects based on the } \\
\text { critical success } \\
\text { factors. } \\
\text { Analysis of new } \\
\text { products }\end{array}$ \\
\hline Core & $\begin{array}{l}\text { To create, select and apply } \\
\text { appropriate techniques, resources } \\
\text { and modern engineering and IT } \\
\text { tools, including prediction and } \\
\text { modelling, to complex engineering }\end{array}$ & $\begin{array}{l}\text { ITES, IT enabled } \\
\text { tools and programs in } \\
\text { design, MIS, etc. }\end{array}$ & $\begin{array}{l}\text { Courses on the IT } \\
\text { enabled tools in } \\
\text { analysis, design, } \\
\text { estimation, } \\
\text { Multimedia } \\
\text { programs, and } \\
\text { learning through You } \\
\text { tube videos related to } \\
\text { industrial } \\
\text { applications. }\end{array}$ \\
\hline Core & $\begin{array}{l}\text { To apply reasoning informed by } \\
\text { contextual knowledge to assess } \\
\text { societal health, safety, legal and } \\
\text { cultural issues and consequent } \\
\text { responsibilities relevant to } \\
\text { professional engineering practice. }\end{array}$ & $\begin{array}{l}\text { Project Management, } \\
\text { Insurance of projects } \\
\text { and workers against } \\
\text { risks, Safety analysis, } \\
\text { Industrial safety, } \\
\text { Safe Work Practices, } \\
\text { Occupational diseases, } \\
\text { Value analysis, } \\
\text { Interdisciplinary } \\
\text { courses }\end{array}$ & $\begin{array}{l}\text { Instructional design } \\
\text { should focus on these } \\
\text { issues. } \\
\text { There should be case } \\
\text { studies, and project } \\
\text { specific research } \\
\text { works, assignments. }\end{array}$ \\
\hline $\begin{array}{l}\text { Advanc- } \\
\text { ed }\end{array}$ & $\begin{array}{l}\text { To understand the impact of } \\
\text { professional engineering solutions } \\
\text { in social and environmental } \\
\text { contexts and demonstrate } \\
\text { knowledge of and need for } \\
\text { sustenance development. }\end{array}$ & $\begin{array}{l}\text { Interdisciplinary } \\
\text { Courses on Climate } \\
\text { Changes; Control of } \\
\text { Greenhouse } \\
\text { Emissions, Clean } \\
\text { Development } \\
\text { Mechanism; Air, } \\
\text { Water, Soil Pollution } \\
\text { Control, } \\
\text { Environmental } \\
\text { Protection, } \\
\text { Environmental } \\
\text { Impact Analysis, } \\
\text { Energy management, } \\
\text { Risk Management, } \\
\text { Disaster Management }\end{array}$ & $\begin{array}{l}\text { The needed courses } \\
\text { are to be incorporated } \\
\text { in all branches of } \\
\text { engineering. } \\
\text { The resource } \\
\text { materials could be } \\
\text { obtained from the } \\
\text { World Bank Institute } \\
\text { and UNESCO. The } \\
\text { video programs could } \\
\text { be downloaded from } \\
\text { these international } \\
\text { development agencies. } \\
\text { Students should be } \\
\text { motivated to prepare to } \\
\text { undertake engineering } \\
\text { projects in these areas. }\end{array}$ \\
\hline
\end{tabular}




\begin{tabular}{|c|c|c|c|}
\hline $\begin{array}{l}\text { Advanc- } \\
\text { ed }\end{array}$ & $\begin{array}{l}\text { To apply ethical principles and } \\
\text { commit to professional ethics and } \\
\text { responsibilities and norms of } \\
\text { engineering practice. }\end{array}$ & $\begin{array}{l}\text { HRD and HRM, } \\
\text { Ethics, Corruption } \\
\text { Elimination, } \\
\text { Professional } \\
\text { Practices, Leadership } \\
\text { Development }\end{array}$ & $\begin{array}{l}\text { Case studies, video } \\
\text { programs, project } \\
\text { specific assignments } \\
\text { are to be included in } \\
\text { the courses. }\end{array}$ \\
\hline $\begin{array}{l}\text { Advance } \\
\text { d }\end{array}$ & $\begin{array}{l}\text { To communicate effectively on } \\
\text { complex engineering activities with } \\
\text { the engineering community and } \\
\text { with society at large, such as being } \\
\text { able to comprehend and write } \\
\text { effective reports and design } \\
\text { documentation, make effective } \\
\text { presentations, and give and receive } \\
\text { clear instructions }\end{array}$ & $\begin{array}{l}\text { Communication, } \\
\text { Report Writing, } \\
\text { Paper Presentation in } \\
\text { the Professional } \\
\text { Seminars, Group } \\
\text { Discussions, Debates, } \\
\text { Participation in } \\
\text { Cultural Programs }\end{array}$ & $\begin{array}{l}\text { Students are to be } \\
\text { guided to present } \\
\text { power points, } \\
\text { technical papers and } \\
\text { solutions to problems } \\
\text { in these areas. }\end{array}$ \\
\hline $\begin{array}{l}\text { Human } \\
\text { Relations }\end{array}$ & $\begin{array}{l}\text { To function effectively as an } \\
\text { individual, and as a member or } \\
\text { leader in diverse teams and } \\
\text { multidisciplinary settings }\end{array}$ & $\begin{array}{l}\text { Interpersonal } \\
\text { relations, Front end } \\
\text { analysis, Work force } \\
\text { Development, } \\
\text { Accepting } \\
\text { Leadership positions } \\
\text { in Student } \\
\text { Associations }\end{array}$ & $\begin{array}{l}\text { Courses in these } \\
\text { areas are to be } \\
\text { included. Necessary } \\
\text { case studies are also } \\
\text { to be included. }\end{array}$ \\
\hline $\begin{array}{l}\text { Professio } \\
\text { nal }\end{array}$ & $\begin{array}{l}\text { To recognize the need for, and have } \\
\text { the preparations and ability to } \\
\text { engage in independent and life-long } \\
\text { learning in the broadest context of } \\
\text { technological change }\end{array}$ & $\begin{array}{l}\text { Competency } \\
\text { Acquisition, Analysis } \\
\text { of Current } \\
\text { Development, } \\
\text { Emerging } \\
\text { Technologies, } \\
\text { Professional } \\
\text { development through } \\
\text { MOOC, Online } \\
\text { programs, } \\
\text { Membership in } \\
\text { Professional } \\
\text { Associations like } \\
\text { ISTE, IEEE, } \\
\text { Institution of } \\
\text { Engineers, ISTD etc. }\end{array}$ & $\begin{array}{l}\text { The students have to } \\
\text { be encouraged to } \\
\text { learn from the } \\
\text { internet, project } \\
\text { reports and case } \\
\text { studies. }\end{array}$ \\
\hline $\begin{array}{l}\text { Professio } \\
\text { nal/ } \\
\text { Leadersh } \\
\text { ip }\end{array}$ & $\begin{array}{l}\text { To demonstrate knowledge and } \\
\text { understanding of engineering and } \\
\text { management principles and apply } \\
\text { these to one's own work, as a } \\
\text { member and leader in a team, to } \\
\text { manage projects and in } \\
\text { multidisciplinary environments }\end{array}$ & $\begin{array}{l}\text { Participation in } \\
\text { Science Exhibitions, } \\
\text { writing articles in the } \\
\text { College Journals, } \\
\text { Annual Publications. }\end{array}$ & $\begin{array}{l}\text { The achievements of } \\
\text { various engineers } \\
\text { have to be prescribed } \\
\text { for mini seminars. }\end{array}$ \\
\hline
\end{tabular}


Curriculum Development Approach

The following four approaches are presented below:

\section{System Approach}

This is one of the approaches where input mostly controls the process which ultimately affects the outcome. One of the major constraints is the nonavailability of qualified and trained faculty. The institutes could recruit adjunct faculty from industries or train the faculty through various modes.

\section{Reverse System Approach}

In this mode, the processes are not diluted and the input is increased sufficiently so that the program is planned and implemented as per the needs of the employers. Institutes with substantial resources, competent faculty and well established IndustryInstitute-Government Partnership could be able to achieve the goal. The mission of the institutes dominates to develop and implement all expected abilities.

3. Specific Industry Relevant Curriculum through Collaboration with the Industry

In this mode, there is close collaboration with a group of industries in the nearby industrial corridors/ hubs. Also the institute could have established good rapport with them.

\section{Cooperative/Sandwich Program}

In this mode, the program itself centers on close cooperation with the group of companies. The students would get needed industrial training and also stipend from the companies under Apprenticeship Scheme of Ministry of Human Resource Development.whenever the companies have openings for new posts, these graduates are preferred.

\section{Credit Based Flexible Curriculum}

This mode is similar to reverse system approach but students would get more flexibility to register a string of courses based on their career needs. They can also get paid internship for a year. But the total credits to be completed would not be changed.

\section{Critical Key Skills}

During rapid growth of industries which are established by Multinational Companies, they select the graduates who possess key/ important skills like productdesign, manufacturing, and maintenance which are very valuable for the company (Table-5).

Table-5 Key Skills

\begin{tabular}{|c|c|c|c|c|}
\hline $\begin{array}{c}\text { Focus at Critical } \\
\text { key Competencies }\end{array}$ & $\begin{array}{c}\text { Program } \\
\text { Educational } \\
\text { Objectives } \\
\text { (PEOs) }\end{array}$ & $\begin{array}{c}\text { Planning } \\
\text { Through } \\
\text { Research }\end{array}$ & $\begin{array}{c}\text { Specific to a } \\
\text { Company }\end{array}$ & $\begin{array}{c}\text { Specific to } \\
\text { Industry }\end{array}$ \\
\hline Product Design & $\begin{array}{c}\text { Advanced } \\
\text { courses and } \\
\text { electives are } \\
\text { introduced }\end{array}$ & $\begin{array}{c}\text { Yes, extensive } \\
\text { literature } \\
\text { survey is } \\
\text { required }\end{array}$ & $\begin{array}{c}\text { Should meet the } \\
\text { needs of the } \\
\text { industry }\end{array}$ & $\begin{array}{c}\text { Yes, could be } \\
\text { capable of taking } \\
\text { interdisciplinary } \\
\text { projects }\end{array}$ \\
\hline Manufacturing & $\begin{array}{c}\text { More industrial } \\
\text { training has to } \\
\text { be incorporated } \\
\text { with relevant } \\
\text { credits }\end{array}$ & $\begin{array}{c}\text { Yes, extensive } \\
\text { needs analyses } \\
\text { are required }\end{array}$ & $\begin{array}{c}\text { Should meet the } \\
\text { needs of the } \\
\text { industry }\end{array}$ & $\begin{array}{c}\text { Yes, but could be } \\
\text { employed in } \\
\text { various } \\
\text { manufacturing } \\
\text { companies }\end{array}$ \\
\hline $\begin{array}{c}\text { Maintenance } \\
\text { collaboration } \\
\text { would yield } \\
\text { proper PEOs }\end{array}$ & $\begin{array}{c}\text { Yes, Needs } \\
\text { palysis has to } \\
\text { performed } \\
\text { employable in } \\
\text { many companies } \\
\text { \&in many other } \\
\text { industries }\end{array}$ \\
\hline $\begin{array}{c}\text { Advanced } \\
\text { Research Courses } \\
\text { Leading to Dual } \\
\text { Degrees }\end{array}$ & $\begin{array}{c}\text { Needs careful } \\
\text { validation }\end{array}$ & $\begin{array}{c}\text { Should meet the } \\
\text { needs }\end{array}$ & $\begin{array}{c}\text { Yesticulously } \\
\text { Yes, but the } \\
\text { leaners could } \\
\text { undertake }\end{array}$ \\
& Yes & No & $\begin{array}{c}\text { advanced research } \\
\text { works, can join } \\
\text { doctoral programs }\end{array}$ \\
\hline
\end{tabular}

In the following Table-6, the institutional assistance for curriculum development that are available in various resource providers are briefly provided: 
Table-6 Institutional Assistance to Plan the Curriculum Planning

\begin{tabular}{|c|c|c|}
\hline Resource Providers & Strengths & Weaknesses \\
\hline $\begin{array}{c}\text { In-house Curriculum } \\
\text { Development Unit }\end{array}$ & $\begin{array}{c}\text { Could complete the project in } \\
\text { time, efficient process } \\
\begin{array}{c}\text { Curriculum Development } \\
\text { Centers of Institutes of } \\
\text { National Importance like IITs/ } \\
\text { IISc/IITDM }\end{array}\end{array}$ & $\begin{array}{c}\text { Efficient and effective teams } \\
\text { could be formed } \\
\text { resource persons from the } \\
\text { industry }\end{array}$ \\
\hline $\begin{array}{c}\text { Boards of Studies of the } \\
\text { Technical Universities }\end{array}$ & $\begin{array}{c}\text { Efficient and effective teams } \\
\text { could be formed }\end{array}$ & $\begin{array}{c}\text { May have to involve many } \\
\text { industrial experts }\end{array}$ \\
\hline $\begin{array}{c}\text { All India Council for } \\
\text { Technical Education } \\
\text { Sponsored Project }\end{array}$ & $\begin{array}{c}\text { Needs more time and efforts, } \\
\text { but Sufficient funds are } \\
\text { available }\end{array}$ & $\begin{array}{c}\text { There is no continuity of } \\
\text { funding for periodical } \\
\text { revision. }\end{array}$ \\
\hline $\begin{array}{c}\text { International Development } \\
\text { Agency Sponsored External } \\
\text { Consultants }\end{array}$ & $\begin{array}{c}\text { Required funds are available, } \\
\text { more consultation with } \\
\text { industry is possible }\end{array}$ & $\begin{array}{c}\text { Ends as one time affair \&faces } \\
\text { limitation for periodical } \\
\text { revision. }\end{array}$ \\
\hline
\end{tabular}

Table-7 Curriculum Revision Process

\begin{tabular}{|c|c|c|c|c|}
\hline Program & Survey Method & $\begin{array}{c}\text { Special Needs of } \\
\text { Indian } \\
\text { Employers }\end{array}$ & $\begin{array}{c}\text { Special Needs of } \\
\text { MNCs }\end{array}$ & $\begin{array}{l}\text { Special Needs of } \\
\text { Research and } \\
\text { Development } \\
\text { Organizations }\end{array}$ \\
\hline $\begin{array}{c}\text { B.E/B.Tech/B.Sc } \\
\text { (Engg) }\end{array}$ & $\begin{array}{l}\text { In-depth survey } \\
\text { of the needs of } \\
\text { industries; } \\
\text { should meet the } \\
\text { norms of AICTE } \\
\text { in duration, title, } \\
\text { courses but } \\
\text { additional } \\
\text { electives could } \\
\text { be given; AICTE } \\
\text { has to approve } \\
\text { the curriculum }\end{array}$ & $\begin{array}{l}\text { To be covered } \\
\text { Through industry } \\
\text { relevant skills; } \\
\text { Can assess the } \\
\text { needs through } \\
\text { the publications } \\
\text { of the Industrial } \\
\text { Association on } \\
\text { the needs of the } \\
\text { industry }\end{array}$ & $\begin{array}{l}\text { Possible to cover } \\
\text { to a large extent } \\
\text { through industry } \\
\text { relevant skills, } \\
\text { May need } \\
\text { industry relevant } \\
\text { programs and } \\
\text { courses through } \\
\text { finishing schools }\end{array}$ & $\begin{array}{l}\text { May need more } \\
\text { advanced courses } \\
\text { in design and } \\
\text { experimentation }\end{array}$ \\
\hline $\begin{array}{l}\text { Postgraduate } \\
\text { Diploma }\end{array}$ & $\begin{array}{l}\text { Focused on the } \\
\text { special needs of } \\
\text { the industry }\end{array}$ & $\begin{array}{l}\text { Generally meet } \\
\text { the special needs }\end{array}$ & $\begin{array}{c}\text { Could largely } \\
\text { meet }\end{array}$ & May meet \\
\hline $\begin{array}{l}\text { M.E/M.Tech / } \\
\text { M.Sc (Engg) }\end{array}$ & $\begin{array}{l}\text { Should meet the } \\
\text { needs of teaching } \\
\text { profession and } \\
\text { also the needs of } \\
\text { the industry; } \\
\text { Should meet the } \\
\text { AICTE's norms } \\
\text { in duration/ } \\
\text { number of } \\
\text { semesters, } \\
\text { course } \\
\text { prescription, and } \\
\text { dissertation }\end{array}$ & $\begin{array}{l}\text { Would meet the } \\
\text { needs in } \\
\text { investigation and } \\
\text { design oriented } \\
\text { works; Could } \\
\text { become } \\
\text { knowledge } \\
\text { oriented } \\
\text { consultancy } \\
\text { projects }\end{array}$ & $\begin{array}{l}\text { Would meet the } \\
\text { high end needs in } \\
\text { design, prototype } \\
\text { development, } \\
\text { testing and } \\
\text { improvement }\end{array}$ & $\begin{array}{l}\text { Should meet the } \\
\text { research oriented } \\
\text { development } \\
\text { works }\end{array}$ \\
\hline $\begin{array}{c}\text { Interdisciplinary } \\
\text { Master Degree } \\
\text { Programs }\end{array}$ & $\begin{array}{l}\text { Should meet the } \\
\text { AICTE's norms, } \\
\text { \&standards }\end{array}$ & $\begin{array}{l}\text { Should meet } \\
\text { meticulously }\end{array}$ & $\begin{array}{l}\text { Should meet } \\
\text { meticulously }\end{array}$ & $\begin{array}{c}\text { Should also meet } \\
\text { meticulously }\end{array}$ \\
\hline $\begin{array}{c}\text { Industry } \\
\text { sponsored } \\
\text { postgraduate } \\
\text { programs }\end{array}$ & $\begin{array}{c}\text { Should } \\
\text { meticulously } \\
\text { meet the needs of } \\
\text { the sponsoring } \\
\text { companies and } \\
\text { related industry }\end{array}$ & Yes & Yes & Yes \\
\hline
\end{tabular}


The curriculum revision process is equally important. The institutes are expected to continuously monitor the technology changes and upgrade the curriculum. Usually survey method is adopted by many institutes. The curricula have to meet the needs of the Indian employers, MNCs and Research and Development organizations. A brief summary is presented in Table-7

\section{Tracer-Study/Longitudinal Study}

Tracer- study/longitudinal study is one of the methods to evaluate the utility, effectiveness course outcomes, efficiency of the curriculum, implementation strategies and methods utilized, student services offered, industry relevant skills and competencies possessed by the graduates of an engineering program. Questionnaires have to be developed to get feedback from the alumni, information from the employers, opinions of the faculty members. The desired information could be collected by properly developed items for which average opinion is required by using Likert's five/ four point scale. An analysis could be displayed through a table. The sum of the learning outcomes would prove the success of the program Educational Objectives. The responses would also provide the real situation and remedial measures that are needed.

Consortium of InstitutesThere is a great need for forming a consortium of institutes for conducting needs analysis from the employers, developing the curricula, conducting the joint evaluation with the representatives of the industry, seeking collaboration for implementation, and getting industrial training, and placement of the graduates. The Ministry of Industries and the Ministry of Education could enact needed Acts which will facilitate such collaborations at state level. The engineering institutes could form appropriate consortium among themselves in each region of the state by forming society. Such consortiums are there in many advanced countries to undertake projects under bilateral agreements. A brief summary is presented in Table-10.

\section{Satellite Centers in the industrial Hubs/Corridors}

Many institutes which are located in far off rural places may find it difficult to get industrial collaboration. Hence, they can plan satellite centers in the industrial hubs and corridors. The Directorate of Technical Education, AICTE, and MHRD could fund such initiatives. Many private -institutes have established such satellite centers in the leading corridors and achieved a lot for training the students.

\section{Outcome Evaluation}

Every Program Educational Objective (PEO) has to be split in to Course Outcomes. Based on the performance of the graduates, the institutes need to get the feedback from the alumni and the employers. This feedback is very much essential for improving the curricula.

The advanced courses and electives have to be revised periodically based on the advancements of the industrial processes, Acts which are due to climate change and desired reduction in the green house emission.

The core courses need to be updated by incorporating developments in the IT enabled tools in design.

\section{Conclusions}

Outcome based curriculum would be demanded by all industries since they depend upon the quality engineering graduates for planning, production, and maintenance. Many institutes face varieties of difficulties in planning and implementing outcome based engineering programs. An attempt has been made to provide a comprehensive documents to the needs of the curriculum developers in India.

The following are the significant suggestions for preparing the outcome based curriculum in engineering:

4 A matrix for planning outcome based curriculum

u A framework for the analysis of performance of the fresh employees

口 Strategies to acquire professional abilities specified in EC2000 of ABET

口 Planning satellite centers, forming consortium of the institutes in the industrial hubs/corridors

\section{Alternate strategies for industrial training}

For the success of economy in the twenty first century, every engineering institute in India has to create high end mission, improve the resources, resource persons and create active participation with industries. Such measures could assist them to plan and implement outcome based engineering programs. 
The participating industries could be given tax concessions so that they can be motivated to continue to support the development of industry ready graduates in engineering and technology.

\section{References}

Abantenba.S (2006)"Development of Strategic Internal Industry Links to Promote undergraduate Education".31,.3,(283-301)

Afonja. A.A, SrakuLatey, K, and Oni, S.A "Engineering Education for Industrial Development: Case Studies of Nigeria, Ghana, and Zimbabwe", A.T.P.S Working Paper No. 42, Kenya Nairobi: The African Technology Policy Studies Network.

Anon (1991) "Outcome-Based Learning: New Name, Old Concept", Training, pp 52-53,

Brandt, R.(1992) "On Outcomes- Based Education: A Conversation with Bill Spady" Educational Leadership, December, 1992.

Daziell.T and Gourvanec.S (2003) "Partnerships in Outcomes Based Education", 12th Teaching and Learning Forum, Edith Cowan University, Perth, Feb.2003

Donnelly. K (2002"Outcomes-Based Curriculum Fails International Comparisons", New Zealand Education Review, October, 2002

DuyenQ.Nguyen (1998) "The Essential Skills of an Engineer: A Comparative Study of Academics, Industry Personnel and Engineering Students". Global Journal of Engineering Education, 2.1

Fakier, M.,Waghid. Y (2004) "On Outcomes-Based Education and Creativity in South Africa", international Journal of Special Education., 19, .2, (53-63)

Holt, M (1994) "WHY Deming and OBE Don't Mix" Educational Leadership, 52,1
International Bureau of Education, UNESCO (2014) 'Postgraduate Diploma in Curriculum Design and Development"

Jansen, J.D (1998) "Curriculum Reform in South Africa": A Critical Analysis of Outcomes-Based Education", Cambridge Journal of Education, 28, 3

Karel, M (2006) "Engineering Curricula in Sustainable Development: An Evaluation of Changes at Delft University of Technology",European Journal of Engineering Education. 31,2, (133-144)

Kati.K, Taira.T, and Minna.T (2007)"New Challenging Approaches to Engineering Education: Enhancing University-Industry Cooperation." European Journal of Engineering Education, V. 32,2, ( 167-179).

Mc Kernan, J. (1993)" Perspectives and ImperativesSome Limitations of Outcomes -Based Education".Journal of Curriculum and Supervision. 8.4, (343-353)

Muhammad.H, Roshid (2013)" The Process of Outcome-based Education-Implementation Assessment and Evaluations" ASEE International Forum, Paper ID\# 8242

Olorunfemi, A.I and Ashaolu, M.O," A Pragmatic Approach in Engineering Education Teaching Methods and Industry Partnership"

Rajee.N, Junaidi.E, Taib.S.N.L.,Salleh and Munot. M.A (2013) "Issues and Challenges in Implementing Outcome Based Education in Engineering Education", International Journal Innovation education and Research, V 1-04

Tavner (2005)"Outcomes-Based Education in a University Setting"Australasian Journal of Engineering Education. 